\title{
Fermentative Production of Imidazoleglycerol with a Histidine Auxotroph of Brevibacterium ammoniagenes
}

\author{
Kazumi Araki* and Hiroshi Hosoda \\ Hofu-plant, Kyowa Hakko Kogyo Co., Ltd., \\ Hofu-shi, Yamaguchi, Japan \\ Received June 11, 1974
}

\begin{abstract}
A histidine auxotroph of Brevibacterium ammoniagenes was found to accumulate imidazoleglycerol in the culture medium. The accumulation of it reached a level of $13 \mathrm{mg} / \mathrm{ml}$ as its monohydrochloride salt with a medium containing $12 \%$ glucose, $2 \%\left(\mathrm{NH}_{4}\right)_{2} \mathrm{SO}_{4}$ and $2.5 \%$ meat extract. By-production of other imidazoles was little.
\end{abstract}

Imidazoleglycerol was found by Ames et al. to be accumulated by histidine auxotrophs of Neurospora and Penicillium. ${ }^{1,2)}$ This finding provided clues to the biosynthetic pathway for histidine in bacterial ${ }^{3 \sim 10)}$ and fungal ${ }^{1,12)}$ systems, in which the phosphate ester of it, i.e., imidazoleglycerol phosphate serves as an intermediate but imidazoleglycerol does not.

During the course of the studies on the fermentative production of amino acids in an industrial scale, we found the accumulation of a large amount of imidazoleglycerol in the culture medium of histidine auxotrophs of Brevibacterium ammoniagenes and Corynebacterium glutamicum. These mutant strains were deposited to The American Type Culture Collection with accession numbers of ATCC 21225 and ATCC 21224, respectively. A part of the data concerning the imidazoleglycerol production with these mutant strains has been described in a patent description. ${ }^{13}$,

This paper describes in some detail the imidazoleglycerol production with $B$. ammoniagenes ATCC 21225 mentioned above.

\section{MATERIALS AND METHODS}

Microorganisms. A histidine auxotroph employed in this experiment was derived from a wild Brevibacterium ammoniagenes strain, ATCC 6872 , by the mutagenic treatment with UV-ray irradiation. The mutant strain has been deposited to The American

\footnotetext{
* Present address: Tokyo Research Laboratory,
} Kyowa Hakko Kogyo Co., Ltd., Machida-shi, Tokyo.
Type Culture Collection with an accession number of ATCC 21225.

Culture method. Fourty milliliters of a seed medium in a $250 \mathrm{ml}$-Erlenmeyer flask was inoculated with a loopful of microorganism grown on a bouillon agar slant, and incubated at $28^{\circ} \mathrm{C}$ on a rotary shaker at $220 \mathrm{rpm}$. After incubation for $24 \mathrm{hr}$, one milliliter of the seed culture was transferred into the same typedflask containing $20 \mathrm{ml}$ of a fermentation medium. This flask was incubated for $72 \mathrm{hr}$ in the same manner as that with the seed culture. The seed medium contained glucose $4 \mathrm{~g}$, peptone $2 \mathrm{~g}$, meat extract $1 \mathrm{~g}$, urea $0.3 \mathrm{~g}$, $\mathrm{KH}_{2} \mathrm{PO}_{4} 0.1 \mathrm{~g}, \mathrm{~K}_{2} \mathrm{HPO}_{4} 0.1 \mathrm{~g}, \mathrm{MgSO}_{4} \cdot 7 \mathrm{H}_{2} \mathrm{O} \quad 0.05 \mathrm{~g}$, $\mathrm{ZnSO}_{4} \cdot 7 \mathrm{H}_{2} \mathrm{O} 0.01 \mathrm{~g}, \mathrm{FeSO}_{4} \cdot 7 \mathrm{H}_{2} \mathrm{O} 0.01 \mathrm{~g}, \mathrm{MnSO}_{2} \cdot 4 \mathrm{H}_{2} \mathrm{O}$ $0.0001 \mathrm{~g}$, biotin $3 \mu \mathrm{g}$, thiamine monohydrochloride $500 \mu \mathrm{g}, \beta$-alanine $500 \mu \mathrm{g}$ per $100 \mathrm{ml}$. The fermentation medium contained $\left(\mathrm{NH}_{4}\right)_{2} \mathrm{SO}_{4} 2 \mathrm{~g}$, urea $0.3 \mathrm{~g}, \beta$ alanine $1.5 \mu \mathrm{g}, \mathrm{FeSO}_{4} \cdot 7 \mathrm{H}_{2} \mathrm{O} 0.002 \mathrm{~g}, \mathrm{ZnSO}_{4} \cdot 7 \mathrm{H}_{2} \mathrm{O}$ $0.0001 \mathrm{~g}, \mathrm{MnSO}_{1} \cdot 4 \mathrm{H}_{2} \mathrm{O} 0.001 \mathrm{~g}$ and $\mathrm{CaCO}_{3} 3 \mathrm{~g}$ per $100 \mathrm{ml}$ as basal ingredients. Glucose, natural nutrients, $\mathrm{KH}_{2} \mathrm{PO}_{4}, \mathrm{Na}_{2} \mathrm{HPO}_{4}$ and $\mathrm{MgSO}_{4}$ were added to the medium at variable levels according to the purpose of each experiment. The hydrogen ion concentration of the media was adjusted to $\mathrm{pH} 7.2$ with $\mathrm{NaOH}$, then the media were sterilized at $120^{\circ} \mathrm{C}$ for $10 \mathrm{~min}$. The fermentation test shown in Fig. 5 was carried out in a 30-liter jar fermentor principally according to the method for the flask-test described above. The details of the test are described in the legend of Fig. 5.

Analysis. The determination of imidazoleglycerol was based on its conversion to imidazoleformaldehyde by periodate oxidation. The assay was similar to that described by Ames et al. ${ }^{14}$ for imidazoleglycerol phosphate, but has been scaled up to ten times the original scale. The standard curve was linear to imidazoleglycerol concentration at least up to $40 \mu \mathrm{g}$ of its monohydrochloride salt. In a sample containing 2.5 or $5.0 \mu \mathrm{g}$ of imidazoleglycerol monohydrochloride 
added to a culture broth (containing $4.2 \mathrm{mg} / \mathrm{ml}$ of imidazoleglycerol accumulated), the added imidazoleglycerol was detected with an efficiency of 104 or $96 \%$, respectively (Table I). A control containing an ali-

Table I. Determination of Imidazoleglycerol Added to a Culture Broth of $B$. ammoniagenes ATCC 21225

Samples containing indicated levels of imdazoleglycerol monohydrochloride in addition to $1 \mu 1$ of a culture broth of ATCC 21225 per $\mathrm{ml}$ were assayed according to the method described in MATERIALS AND METHODS.

\begin{tabular}{|c|c|c|}
\hline $\begin{array}{c}(\mathrm{A}) \\
\text { Imidazoleglycerol } \\
\text { monohydro- } \\
\text { chloride } \\
\text { added }(\mu \mathrm{g} / \mathrm{ml})\end{array}$ & $\begin{array}{c}\text { (B) } \\
\text { Imidazoleglycerol } \\
\text { monohydro- } \\
\text { chloride } \\
\text { determined }(\mu \mathrm{g} / \mathrm{ml})\end{array}$ & $\frac{\begin{array}{c}\text { Recovery } \\
\mathrm{B}-4.2\end{array}}{\mathrm{~A}} \times 100 \%$ \\
\hline 0.0 & $4.2^{a 1}$ & \\
\hline 2.5 & 6.8 & 104 \\
\hline 5.0 & 9.0 & 96 \\
\hline
\end{tabular}

a) The value, 4.2 shows the amount of imidazoleglycerol accumulated in the culture broth.

quot of a fermentation medium without being inoculated with microorganisms was assayed, and an appropriate correction was made using this control for the estimation of imidazoleglycerol accumulated in the culture broth. The growth of microorganisms was measured by reading the absorbancy at $660 \mathrm{~nm}$ of the culture broth in a cuvette with a light-path of $0.5 \mathrm{~cm}$ using Tokyo Koden Model ANA 7A colorimeter, after dissolving the $\mathrm{CaCO}_{3}$ in the medium with $\mathrm{HCl}$ and 20-fold dilution.

Reagent. D-Erythro-imidazoleglycerol was kindly supplied by Dr. B. N. Ames.

Isolation of imidazoleglycerol. Imidazoleglycerol was isolated from the culture broth according to the procedure shown in Fig. 1. It was done by passage the solution containing imidazoleglycerol through the columns of $\mathrm{H}^{+}-$form of cation exchange resins (Diaion SK\#1 and Amberlite IRC-50) and by elution with $1 \mathrm{~N} \mathrm{NH} \mathrm{NH}_{4} \mathrm{OH}$. The eluate was then concentrated to make $6.5 \%$ solution of imidazoleglycerol, decolorized with carbon, adjusted to $\mathrm{pH} 3.0$ with $\mathrm{HCl}$, and further concentrated to dryness. Imidazoleglycerol was extracted from the residue with $98 \%$ ethanol and recrystallized in the form of monohydrochloride from the ethanol solution.

\section{RESULTS}

\section{Identification of imidazoleglycerol}

$B$. ammoniagenes ATCC 21225 was found to
Culture broth

-filtrated.

-pH adjusted to 2.0 with $\mathrm{H}_{2} \mathrm{SO}_{4}$.

-passed through Diaion SK\#1 $\left(\mathrm{H}^{+}\right)$

-eluated with $1 \mathrm{~N} \mathrm{NH}_{4} \mathrm{OH}$.

Eluate

-concentrated in vacuo.
-passed through IRC-50 $\left(\mathrm{H}^{+}\right)$.
-eluted with $1 \mathrm{~N} \mathrm{NH}_{4} \mathrm{OH}$.

Eluate

-concentrated in vacuo to make $6.5 \%$

imidazoleglycerol concentration.

-decoloured with carbon.

$-\mathrm{pH}$ adjusted to 3.0 with $\mathrm{HCl}$.

- concentrated to dryness.

Crude crystals

extracted with $98 \%$ ethanol.

FrG. 1. Isolation of Imidazoleglycerol from Culture Broth.

produce a diazosulfanilic acid reaction-positive substance in the culture broth. It was isolated in a crystalline form by the procedure described in Materials and Methods section. $[\alpha]_{D}^{20}+$ 10.18(C4, $\left.\mathrm{H}_{2} \mathrm{O}\right)$, mp $121.5 \sim 126.8^{\circ} \mathrm{C}^{*}$ Anal. Calcd. for $\mathrm{C}_{6} \mathrm{H}_{10} \mathrm{~N}_{2} \cdot \mathrm{HCl}: \mathrm{C}, 37.10 ; \mathrm{H}, 5.67$; $\mathrm{N}, 14.43$. Found: $\mathrm{C}, 36.91 ; \mathrm{H}, 6.34 ; \mathrm{N}, 15.42$. This compound had the same $R f$-values with authentic imidazoleglycerol in paperchromatography with five solvent systems, as shown in Table II. Like authentic imidazoleglycerol, it

Table II. Paperchromatographic IDENTIFICATION OF IMIDAZOLEGLYCEROL

$R f$-values of the spots of imidazoleglycerol which were located with diazosulfanilic acid reagent are given.

\begin{tabular}{ccc}
\hline $\begin{array}{c}\text { Solvent } \\
\text { system }^{a 1}\end{array}$ & $\begin{array}{c}\text { Imidazoleglycerol } \\
\text { isolated from } \\
\text { culture broth }\end{array}$ & $\begin{array}{c}\text { Authentic } \\
\text { imidazoleglycerol }\end{array}$ \\
\hline $\mathrm{a}$ & 0.565 & 0.565 \\
$\mathrm{~b}$ & 0.476 & 0.476 \\
$\mathrm{c}$ & 0.156 & 0.156 \\
$\mathrm{~d}$ & 0.096 & 0.106 \\
$\mathrm{e}$ & 0.409 & 0.409 \\
\hline
\end{tabular}

a) Solvent system (ratio by volume): a, $n$-propanol$0.2 \mathrm{~N} \mathrm{NH}_{4} \mathrm{OH}(3: 1) ; \mathrm{b}, n$-propanol-N acetic acid (3:1); c, $n$-butanol-acetic acid- $\mathrm{H}_{2} \mathrm{O}(5: 2: 2)$; d, acetone-chloroform- $\mathrm{H}_{2} \mathrm{O}-28 \% \mathrm{NH}_{4} \mathrm{OH}(30: 5$ : 4:0.2); e, $n$-butanol-acetic acid-ethylacetate- $\mathrm{H}_{2} \mathrm{O}$ $(1: 1: 1: 1)$.

* The melting point of the isolated crystal was in good agreement with that $\left(126.5^{\circ} \mathrm{C}\right)$ of authentic imidazoleglycerol, but it was somewhat higher than the value $\left(102.5 \sim 103^{\circ} \mathrm{C}\right)$ described by Ames et al. in a previous paper. ${ }^{2 !}$ 


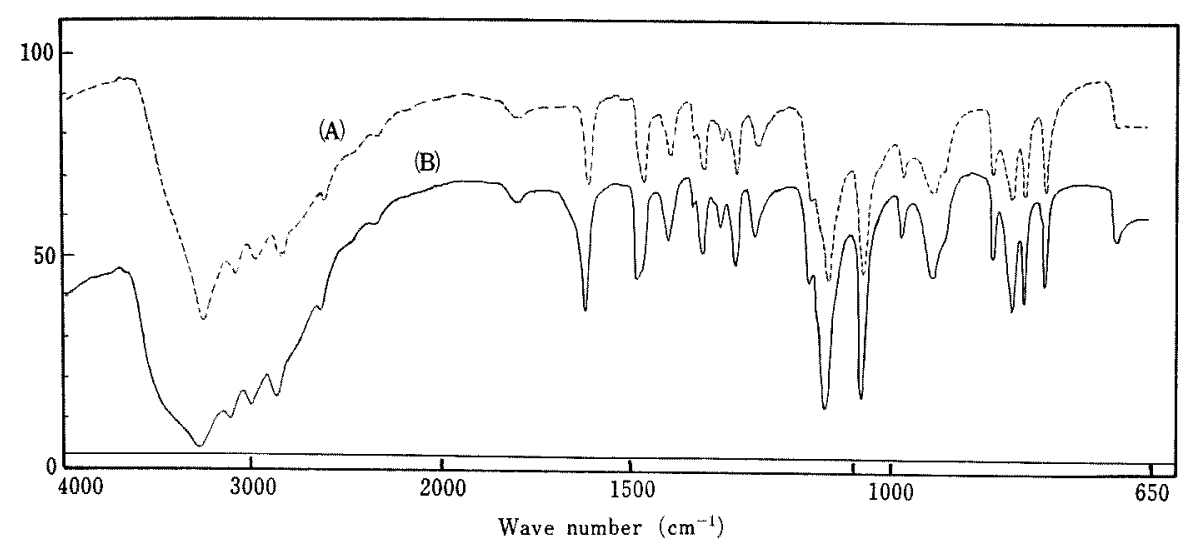

FIG. 2. Infrared Spectrum of Imidazoleglycerol (monohydrochloride).

A: Authentic imidazoleglycerol. B: Imidazoleglycerol isolated from broth.

was converted to imidazoleformaldehyde by oxidation with periodic acid, accomplished according to the method of Ames et al. ${ }^{2)}$ Moreover, it gave the same absorption spectrum of the chromatophore when reacted with diazosulfanilic acid $^{15)}$ with that from authentic imidazoleglycerol. The infrared spectrum of the crystal coincided with that of authentic imidazoleglycerol as shown in Fig. 2. From these results, the substance produced by ATCC 21225 was concluded to be imidazoleglycerol.

\section{Effect of growth factor}

In the fermentative production of amino acids with bacterial auxotrophs, supplying of the required substances in a level suboptimal for growth gives the maximal yield of amino acids. $^{16)}$ The effect of histidine and natural nutrients containing histidine on imidazoleglycerol production was tested, because ATCC 21225 requires histidine for growth. As shown in Table III, more than $5 \mathrm{mg}$ (as monohydrochloride) per $\mathrm{ml}$ of imidazoleglycerol was produced when acid-hydrolyzate of $C$. glutamicum cells, acid-hydrolyzate of soybean meal or meat extract was added to the medium at $1 \sim 3 \%$ levels. At a high level $(4 \%)$ of the natural nutrients, the yield of imidazoleglycerol was distinctly reduced.

When L-histidine monohydrochloride was used as the growth factor, the high amount $(4.5 \sim 5.1 \mathrm{mg} / \mathrm{ml}$, as monohydrochloride) of
TABle III. EfFect OF Histidine AND Natural Nutrients on Imidazoleglycerol Production

Fermentation medium basically contained $12 \%$ glucose, $0.2 \% \mathrm{KH}_{2} \mathrm{PO}_{4}, 0.2 \% \mathrm{Na}_{2} \mathrm{HPO}_{4}, 0.1 \% \mathrm{MgSO}_{4}$. $7 \mathrm{H}_{2} \mathrm{O}$, and the basal ingredients described in MATERIALS AND MeTHODs section.

\begin{tabular}{llcc}
\hline \multicolumn{1}{c}{ Additions (\%) } & $\begin{array}{c}\text { Growth } \\
(\mathrm{O} . \mathrm{D} .660 \\
\mathrm{nm} \times 1 / 20)\end{array}$ & $\begin{array}{c}\text { Imidazoleglycerol } \\
\text { accumulated } \\
(\mathrm{mg} / \mathrm{ml})^{a)}\end{array}$ \\
\hline Acid- & $(4)$ & 0.78 & 3.2 \\
hydrolyzate & $(3)$ & 0.82 & 5.0 \\
of cells of & $(2)$ & 0.84 & 6.8 \\
C. glutamicum & $(1)$ & 0.77 & 5.9 \\
Acid- & $(4)$ & 0.79 & 2.9 \\
hydrolyzate & $(3)$ & 0.78 & 6.8 \\
of soybean & $(2)$ & 0.80 & 7.7 \\
meal & $(1)$ & 0.66 & 5.5 \\
& $(4)$ & 0.62 & 1.3 \\
Meat extract & $(3)$ & 0.70 & 8.6 \\
& $(2)$ & 0.59 & 8.1 \\
& $(1)$ & 0.52 & 7.4 \\
No addition & & 0.07 & 1.2 \\
\hline
\end{tabular}

a) As monohydrochloride.

imidazoleglycerol was produced under the condition with comparably high concentration, i.e., $600 \sim 1200 \mu \mathrm{g}$ as monohydrochloride per $\mathrm{ml}$ or $3.1 \sim 6.2 \mathrm{~mm}$ of L-histidine (Fig. 3). Addition of much higher amount of histidine ( $2400 \mu \mathrm{g}$ as monohydrochloride per $\mathrm{ml}$ ) reduced the imidazoleglycerol production only by $27 \%$ of the maximal yield. The cellular growth did not distinctly respond to the hist- 
idine concentrations upto $2400 \mathrm{~g}$ (as monohydrochloride) $/ \mathrm{ml}$. These results are in remarked contrast with the cases of imidazoleglycerol production ${ }^{22}$ and histidinol production $^{23)}$ by histidine auxotrophs of $C$. glutamicum, where addition of $1 \mathrm{~mm}$ histidine to the medium gave the maximal yield of the products and increasing the histidine level to $2 \mathrm{~mm}$ reduced the yield by $50 \%$ or more. In these cases, moreover, the growth of the mutants responded to histidine concentrations. The reason is unclear why the cellular growth and the imidazoleglycerol production with B. ammoniagenes ATCC 21225 studied here were less effectively affected by histidine in comparison with the cases of imidazoleglycerol production and histidinol production by the C. glutamicum mutants. Some difference between histidine-permeabilities of these two microorganisms, if it exists, might offer an explanation to these phenomena.

At the histidine-concentrations of $75 \sim 150 \mu \mathrm{g}$ as monohydrochloride per $\mathrm{ml}$, the growth level of ATCC 21225 was rather higher than the case with excess of histidine. Such a high level of growth under histidine-limitation has also been observed in the cases of the above-described imidazole-productions by histidine auxotrophs of $C$. glutamicum. This may be ascribed to the appearance of non-auxotrophic revertants from ATCC 21225 during the fermentation.

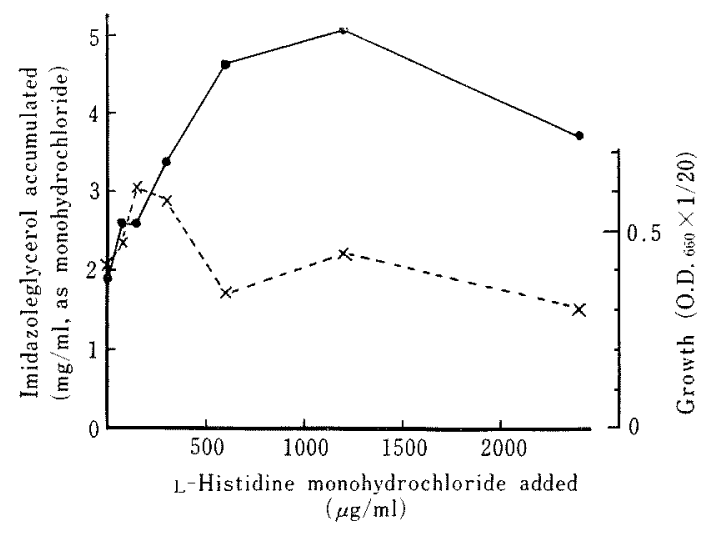

FIG. 3. Effect of L-Histidine on Imidazoleglycerol Production by $B$. ammoniagenes ATCC 21225.

- - imidazoleglycerol; $x--x$, growth. Fermentation medium was the same as that in Table III.
3. Effect of inorganic phosphate and magnesium

Based on the informations on histidine pathway in other microorganisms, ${ }^{3 \sim 12,17)}$ it may be assumed that ATCC 21225 forms imidazoleglycerol from its phosphate ester through the action of phosphatase. Because the phosphatase specific to imidazoleglycerol phosphate has not been found in microorganisms, to our knowledge, it is possible that non-specific phosphatase may participate in its formation. Furthermore, inorganic phosphate is known to repress the formation of acid- and alkaline phosphatases in some microorganisms..$^{18,19)}$ Accordingly, it was of interest to test the effect of inorganic phosphate on imidazoleglycerol production by ATCC 21225 . Effect of magnesium ion was also tested, because increasing in the concentrations of $\mathrm{MgSO}_{4} \cdot 7 \mathrm{H}_{2} \mathrm{O}$ as well as $\mathrm{KH}_{2} \mathrm{PO}_{4}$ and $\mathrm{K}_{2} \mathrm{HPO}_{4}$ is shown ${ }^{20}$ ) to stimulate the inosinic acid production by an adenine auxotroph of $B$. ammoniagenes. In the test, $\mathrm{KH}_{2} \mathrm{PO}_{4}$ and $\mathrm{Na}_{2} \mathrm{HPO}_{4}, \mathrm{MgSO}_{4} \cdot 7 \mathrm{H}_{2} \mathrm{O}$ and meat extract were added to the medium as the sources of inorganic phosphate, magnesium ion and histidine, respectively. The results are shown in Table IV. It can be seen that

\section{TTable IV. Effect of Inorganic Phosphate and Magnesium Sulfate Concentration on IMIDAZOLEGLYCerol Production}

Fermentation medium basically contained $12 \%$ glucose, $2.5 \%$ meat extract, and the basal ingredients described in MATERIALs AND Methods.

\begin{tabular}{cccc}
\hline $\begin{array}{c}\text { Phosphate } \\
\text { salts } \\
\text { added } \\
(\%)\end{array}$ & $\begin{array}{c}\mathrm{MgSO}_{4} . \\
7 \mathrm{H}_{2} \mathrm{O} \\
\text { added } \\
(\%)\end{array}$ & $\begin{array}{c}\text { Growth } \\
(\text { O.D.660 }\end{array}$ & $\begin{array}{c}\text { Imidazoleglycerol } \\
\text { accumulated } \\
(\mathrm{mg} / \mathrm{ml})^{\alpha .1}\end{array}$ \\
\hline $\mathrm{KH}_{2} \mathrm{PO}_{4}(2)$ & 2.00 & 0.63 & 13.1 \\
$\mathrm{Na}_{2} \mathrm{HPO}_{4}(2)$ & 1.00 & 0.58 & 11.8 \\
& 0.05 & 0.46 & 10.7 \\
$\mathrm{KH}_{2} \mathrm{PO}_{4}(0.1)$ & 2.00 & 0.68 & 11.6 \\
$\mathrm{Na}_{2} \mathrm{HPO}_{4}(0.1)$ & 1.00 & 0.68 & 9.4 \\
\hline
\end{tabular}

a) as monohydrochloride.

high concentration $(2 \%)$ of the phosphates reduced the growth when the concentration of the magnesium salt was low $(0.05 \%)$. The growth-inhibition was released by the addition of high levels $(1 \sim 2 \%)$ of the magnesium salt 
to the medium. At the higher level (each $2 \%$ ) of the phosphates, imidazoleglycerol production increased with the increase of the growth levels or magnesium concentrations. At the low level (each $0.1 \%$ ) of the phosphates, the concentration of magnesium ion did not affect the growth level. Moreover, the correlation between magnesium ion concentration and imidazoleglycerol production was obscure. The maximal amount of imidazoleglycerol produced at the two different levels of the phosphates was almost the same, while by-production of other unidentified substances which were positive to diazosulfanilic acid reaction was distinctly reduced at $2 \%$ level of the phosphates, as shown in Fig. 4.

\begin{tabular}{|c|c|c|c|c|c|c|}
\hline \multirow[t]{2}{*}{$\begin{array}{l}\text { Phosphates } \\
\text { added }(\%)\end{array}$} & \multicolumn{2}{|c|}{$\begin{array}{c}\mathrm{MgSO}_{4} \cdot 7 \mathrm{H}_{2} \mathrm{O} \\
\text { added }(\%)\end{array}$} & \multicolumn{3}{|c|}{$R f$-value } & \\
\hline & & & & 0.5 & & \\
\hline $\begin{array}{l}\mathrm{KH}_{2} \mathrm{PO}_{4}(2) \\
\mathrm{Na}_{2} \mathrm{HPO}_{4}(4)\end{array}$ & $\begin{array}{l}2.00 \\
1.00 \\
0.05\end{array}$ & J & & 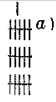 & & \\
\hline $\begin{array}{l}\mathrm{KH}_{2} \mathrm{PO}_{4}(0.1) \\
\mathrm{Na}_{2} \mathrm{HPO}_{4}(0.1)\end{array}$ & $\begin{array}{l}2.00 \\
1.00 \\
0.05\end{array}$ & - & $\begin{array}{l}+ \\
+ \\
+\end{array}$ & $\begin{array}{l}\text { H⿻川 } \\
\text { H\#t } \\
\text { Wm }\end{array}$ & $\frac{\frac{1}{1}}{+}$ & \\
\hline
\end{tabular}

Fig. 4. By-production of the Substances Positive to Diazosulfanilic Acid Reaction in Imidazoleglycerol Fermentation with $B$. ammoniagenes ATCC 21225 .

The culture broth obtained in the experiment shown in Table IV was paper-chromatogramed on Toyo Roshi No. 50 with the solvent system $n$-propanol$0.2 \mathrm{~N} \mathrm{NH}_{4} \mathrm{OH}$ (3: 1 by volume). The marks, $\mathrm{H}$, 册,,$+ \perp$, and \pm show the locations of the coloured spots, in order of decreasing density.

a) Imidazoleglycerol.

\section{Chemical changes during fermentation}

The time course of imidazoleglycerol fermentation in a 30 -liter jar fermentor is exemplified in Fig. 5. The production of imidazoleglycerol paralleled with the growth until $30 \mathrm{hr}$ and continued to increase even in the stationary phase of growth, being accompanied by the consumption of glucose.

\section{DISCUSSION}

A histidine auxotroph, Brevibacterium ammoniagenes ATCC 21225 accumulated a large amount of imidazoleglycerol in the culture medium. Though it has not been verified

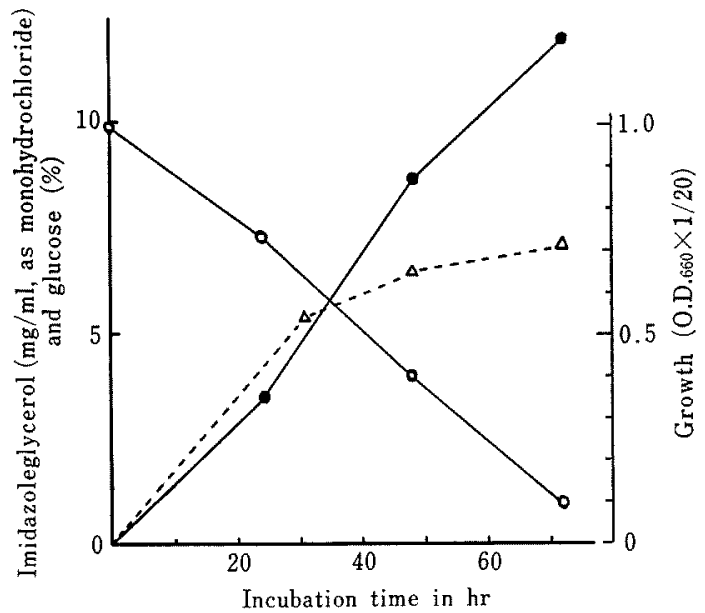

FIG. 5. Time Course of Imidazoleglycerol Fermentation.

-- Imidazoleglycerol; $\triangle--\triangle$, Growth; $\bigcirc-0$, Glucose. Fermentation was carried out in a 30-liter jar fermentor containing 15 liters of a fermentation medium comprising of $10 \%$ glucose, $3 \%$ meat extract, $2 \% \quad \mathrm{KH}_{2} \mathrm{PO}_{4}, 2 \% \mathrm{Na}_{2} \mathrm{HPO}_{4}, 2 \% \mathrm{MgSO}_{4}$. $7 \mathrm{H}_{2} \mathrm{O}$ and basal ingredients. Cutlure conditions: Aeration, 10 liters/min; agitation, $400 \mathrm{rpm}$.

The hydrogen ion concentration was automatically controlled with $\mathrm{NH}_{4} \mathrm{OH}$ to $\mathrm{pH} 7.0$ during fermentation.

whether imidazoleglycerol phosphate is accumulated or not, its accumulation would be little, if it occurs, in view of the trace amount of other diazosulfanilic acid-positive spots on the paperchromatogram of the culture broth. These facts suggest that the histidine-auxotrophy of this mutant is due to the genetic block at imidazoleglycerol phosphate dehydratase (EC 4.2.1.19), ${ }^{4,17}$, the enzyme converting imidazoleglycerol phosphate to imidazoleacetol phosphate in the histidine pathway. The reason for the preferential production of imidazoleglycerol to its phosphate ester by this mutant may reside in the existence of the permeability batrier to the phosphate ester, the dephosphorylation of the phosphate ester through the action of some phosphatase, and excretion into the medium in the form of imidazoleglycerol. This assumption is suggested by an interpretation relevant to permeability change, which has been made for the interchangable accumulation of inosinic acid 
and hypoxathine by an adenine-auxotroph derived from $B$. ammoniagenes ATCC 6872 from which ATCC 21225 studied here also originated.

Acknowledgement. The authors are grateful to Dr. B. N. Ames for gifts of imidazoleglycerol and imidazoleacetol, and to Dr. K. Nakayama for reading the manuscript and for suggesting improvement. Thanks are also due to Mr. M. Ikumo for his technical help.

\section{REFERENCES}

1) B. N. Ames and H. K. Mitchell, J. Amer. Chem. Soc., 74, 252 (1952).

2) B. N. Ames, H. K. Mitchell and M. B. Mitchell, ibid., 75, 1015 (1953).

3) H. S. Moyed and B. Magasanik, J. Biol. Chem., 235, 149 (1960).

4) M. Brenner and B. N. Ames, "Metabolic Pathways," Vol. V, ed. by H. J. Vogel, Academic Press Inc., New York, 1971, p. 349.

5) L. F. Chapman and E.W. Nester, J. Bacteriol., 97, 1444 (1969).

6) E. P. Goldschmidt, M. S. Cater, T.S. Matney, M. A. Bulter and A. Green, Genetics, 66, 219 (1970).

7) M. E. Burke and P. A. Pattee, Can. J. Microbiol, 18, 569 (1972).
8) C. Kane-Falace, M. Musselwhite and W.E. Kloos Bacteriol. Proc., 1971, p. 161.

9) S. Russi, A. Carere, B. Fratells and V. Kloudkormoff, Ann. Super. Sonita, 2, 506 (1966).

10) B. J. Mee and B. T. O. Lee, Genetics, 55, 709 (1967).

11) G. R. Fink, Science, 146, 525 (1964).

12) M. B. Berlyn, Genetics, 57, 561 (1967).

13) British Patent 1201747 (1970).

14) B. N. Ames, R. G. Martin and B. J. Garry, J. Biol. Chem., 236, 2019 (1961).

15) H. T. Mcpherson, Biochem. J., 40, 470 (1946).

16) K. Nakayama, "Genetics in Industrial Microorganisms,'” Vol. I; Bacteria, ed. by Z. Vanèk, Z. Host'álech and J. Culdin, Elsvier Publ., London, 1973, p. 219.

17) D. M. Greenberg, "Metabolic Pathway," Vol. III, ed. by D. M. Greenberg, Academic Press, New York and London, 1969, p. 268.

18) T. Horiuchi, S. Horiuchi and D. Mizuno, Nature, 183, 1529 (1959).

19) M. Misawa, T. Nara and K. Nakayama, Nippon Nógeikagaku Kaishi, 38, 167 (1964).

20) T. Nara, M. Misawa and S. Kinoshita, Agr. Biol. Chem., 31, 1351 (1967).

21) A. Furuya, S. Abe and S. Kinoshita, ibid., 34, 210 (1970).

22) K. Araki and K. Nakayama, ibid., 38, 2219 (1974).

23) K. Araki and K. Nakayama, ibid., in press. 